\title{
Investigating the Effect of the Organ Transplantation and Donation Education Given To Nursing Students
}

\author{
Siddika Ersoy \\ Suleyman Demirel University, Faculty of Health Science, \\ Department of Nursing, Division of Medical Nursing, Isparta, Turkey, \\ E-mail: siddikaersoy@gmail.com
}

\begin{abstract}
Objective: This study was carried out to investigate the effect of the education given to nursing students regarding organ transplantation and donation. Method: This study was carried out with second year students attending the health sciences faculty of a public university. The population of the study consisted of students attending the Internal Medicine Nursing course during the 2017-2018 academic year. Sample selection was not performed, and all the students who took this course were included into the study sample. The study was completed with 282 people. Results: The mean age of the students was $21.24 \pm$ 13.04, and $72.4 \%$ were female. According to the pre-test results, it was found that $98.9 \%$ of the participants were not organ donors, with $30.2 \%$ of the students stating that their reason for not becoming donors was the fear of being killed/insecurity. There was a statistically significant difference in the level of knowledge and attitudes of the students about organ transplantation and donation before and after the education ( $\mathrm{p}<0.001$ ), and it was determined that education increased their level of knowledge. Conclusion: Organ transplantation and organ donation are becoming a global issue due to the increase in chronic diseases. Appropriate curriculum changes in undergraduate education will ensure the training of healthcare professionals with sufficient knowledge and persuasiveness on this subject.
\end{abstract}

Keywords: Organ transplantation, organ donation, nursing, student, education

DOI: $10.7176 / J S T R / 5-6-10$

\section{Introduction}

The most significant factor behind the global increase in organ transplantation waiting times and deaths in long waiting lists is the insufficiency of donated organs (Reville et al,2013). Organ transplantation is defined as the process of transplanting a healthy tissue or organ from a living or dead donor to replace a tissue or organ that is unable to perform its function in the body. Organ donation is the act where individuals, with free thought and will, give permission while still alive or after the diagnosis of brain death for their organs to be used in the treatment of suitable patients (T.C. Sağlık Bakanlığı, 2019).

The most important requirement for organ transplantation is finding a healthy organ and obtaining an approval for donation/transplantation. Despite the developments and support provided in Turkey, problems related to this requirement still continue to be a major problem, just as it is the case in the rest of the world ( Sipkin et al, 2010). Organ transplantation is the most effective treatment for irreversible organ failure, and it gives patients a second chance to live, which makes organ donation and transplantation even more important (Demir Doğan et al, 2016; Webb G et al, 2015; Barbara, 2006). In Turkey, transplantation of cadaveric organs is not possible without the consent of the family, even if the individuals donate their organs while they are alive. To ensure that families have a positive attitude towards the organ donation process, the decision to donate of the donor must be supported by his/her family. To this end, it is important for healthcare professionals to have sufficient knowledge about organ donation, and that they approach donors and families in a sensitive and understanding manner (Demir Doğan et al, 2016; Alsaied et al, 2012; Yilmaz, 2011; Akgün et al; 2003).

In order for healthcare professionals to create systems that will help guide patients to organ donation, patients and families need more information and training about the organ donation process during the 
medical and psychosocial care period, before the end of life takes place. It has been emphasised that protocols and training materials developed together with healthcare workers should be used to best support this process (Michetti et al, 2016). Therefore, healthcare professionals should first of all have sufficient knowledge about the subject. It has been suggested that organ transplantation education should be started at the undergraduate level, to ensure that healthcare professionals can gain adequate knowledge on the subject. In this respect, it has been emphasised that the adoption rate of organ donation by families will likely increase in parallel with the level of competence and proficiency of healthcare professionals (Demir Doğan et al, 2016). This study was carried out to investigate the effect of the education given to nursing students regarding organ transplantation and donation.

\section{Materials and Methods}

This study was carried out with second year students attending the health sciences faculty of a public university. The population of the study consisted of students attending the Internal Medicine Nursing course during the 2017-2018 academic year. Sample selection was not performed, and all of the students who took this course were included in the study sample. Students who did not take the pre-test or posttest were excluded from the study, and the study was completed with 282 people.

Internal Medicine Nursing course is a one-semester course that covers 14 weeks and is given eight hours per week. During this course, education on organ transplantation and donation is provided to the students on the $9^{\text {th }}$ week through a two-hour class. The questionnaire developed by the researcher consists of two parts and 25 items. The first part comprises questions on the sociodemographic characteristics of the students, while the second part comprises the questions prepared to determine the level of knowledge and attitudes of students about organ transplantation and donation. The questionnaire was applied as a pre-test in the first week of the course. After the topic of organ donation was covered in the $9^{\text {th }}$ week, the same questionnaire was administered again as a post-test.

The study data were evaluated by SPSS for Windows 20.0 program and number, percentage, McNemar and McNemar-Bowker tests were used for statistical analysis. A value of $\mathrm{p}<0.01$ was considered as statistically significant.

\section{Results}

The mean age of the students was $21.24 \pm 13.04$, and $72.4 \%$ were female, while $27.6 \%$ were male. It was found that $35.9 \%$ of the mothers of the students and $40.8 \%$ of their fathers were high school graduates. According to the pre-test results, it was found that $98.9 \%$ of the participants were not organ donors, and $30.2 \%$ of the students stated that their reason for not becoming donors was the fear of being killed/insecurity. When asked "Is there a legal regulation on organ donation in Turkey?", only $3.5 \%$ of the students answered "Yes". More than half of the students (61.4\%) stated that they had no knowledge, and all of the students stated that identity card and health reports need to be present in order to make organ donation (Table 1).

Table 2 shows the comparison of the levels of knowledge of the participants regarding organ donation before and after the education. There was a statistically significant difference in the level of knowledge and attitudes of the students about organ transplantation and donation before and after the education ( $\mathrm{p}$ $<0.001$ ), and it was determined that education increased the level of knowledge. When the participants were asked about the legal possibility of selling organs for money in Turkey, it was found that there was a statistically significant difference between the answers before and after the education. Of the participants, $96.3 \%$ did not have an idea on this issue before the education, whereas after the education, $99.0 \%$ answered that selling organs for money is illegal. A statistically significant difference was found in the answers given to the question "Under which conditions can organ transplantation be carried out from a person who has not previously requested organ donation?" between the pre-test and the post-test $(p<0.001)$. Before the education, all of the students stated that doctor approval was enough, whereas after the education, all of the students (100.0\%) gave the correct answer to this question.

Table 3 shows the distribution of students' attitudes about organ donation. There was a statistically significant difference between participants' attitudes about organ donation before and after education ( $\mathrm{p}$ $<0.001$ ) (Table 3). 
Table 1. The distribution of sociodemografic characteristics of the students $(n=282)$

\begin{tabular}{|c|c|c|}
\hline Sociodemografic characteristics & Number & $\%$ \\
\hline \multicolumn{3}{|l|}{ Mother education status } \\
\hline Primary school graduate & 66 & 23.4 \\
\hline Middle School Graduate & 88 & 31.2 \\
\hline High school graduate & 101 & 35.9 \\
\hline Graduated from a Universty & 27 & 9.5 \\
\hline \multicolumn{3}{|l|}{ Father education status } \\
\hline Primary school graduate & 50 & 17.7 \\
\hline Middle School Graduate & 75 & 26.6 \\
\hline High school graduate & 115 & 40.8 \\
\hline Graduated from a Universty & 42 & 14.9 \\
\hline \multicolumn{3}{|l|}{ Did you donate your organs? } \\
\hline Yes & 3 & 1.1 \\
\hline No & 279 & 98.9 \\
\hline \multicolumn{3}{|c|}{ If you don't donate your organs, what is the reason? } \\
\hline Faith & 47 & 16.6 \\
\hline My family & 54 & 19.2 \\
\hline Esthetic anxiety & 7 & 2.4 \\
\hline I'm younger & 21 & 7.4 \\
\hline I don't think about it & 68 & 24.2 \\
\hline Fear of death / insecurity & 85 & 30.2 \\
\hline \multicolumn{3}{|c|}{ Is there a legal regulation on organ donation in our country? } \\
\hline Yes & 10 & 3.5 \\
\hline No & 158 & 56.1 \\
\hline I dont know & 114 & 40.4 \\
\hline \multicolumn{3}{|c|}{ Where do you get information about organ donation? } \\
\hline From Internet & 62 & 21.9 \\
\hline From tv. & 38 & 13.4 \\
\hline My private doctor & 0 & 0.0 \\
\hline Organ donation from the center & 3 & 1.1 \\
\hline Environment & 6 & 2.2 \\
\hline No knowledge & 173 & 61.4 \\
\hline \multicolumn{3}{|c|}{ Which units / units can you donate organ? } \\
\hline Family medicine center & 7 & 2.4 \\
\hline Dispensaries & 3 & 1.1 \\
\hline Private polyclinics & 39 & 13.9 \\
\hline Public hospitals & 12 & 4.2 \\
\hline University hospitals & 137 & 48.6 \\
\hline Provincial Health Directorate & 84 & 29.8 \\
\hline
\end{tabular}


International Journal of Scientific and Technological Research

ISSN 2422-8702 (Online), DOI: 10.7176/JSTR/5-6-10

Vol.5, No.6, 2019

\begin{tabular}{|l|l|l|}
\hline What is required for organ donation? & 282 & 100.0 \\
\hline ID & 282 & 100.0 \\
\hline Health report & 18 & 6.3 \\
\hline Two close relatives & 15 & 5.3 \\
\hline Only my doctor's knowledge & 2 & 0.5 \\
\hline Do you have any organ donors in your relatives or near you? & \multicolumn{2}{|l|}{} \\
\hline Yes & 91 & 268 \\
\hline No & 246 & 72.7 \\
\hline I dont know & \multicolumn{2}{|l|}{} \\
\hline Are there any relatives waiting for an organ transplant in your relatives or near you? \\
\hline Yes & 0 & 0.0 \\
\hline No & 252 & 74.3 \\
\hline I dont know & 87 & 25.7 \\
\hline
\end{tabular}


Table 2. The distribution of knowledge level questions about organ donation before and after education

\begin{tabular}{|c|c|c|c|c|c|c|}
\hline \multirow{2}{*}{\multicolumn{2}{|c|}{ Questions }} & \multicolumn{2}{|c|}{ Before education } & \multicolumn{2}{|c|}{ After education } & \multirow[t]{2}{*}{$\mathbf{p}$} \\
\hline & & Number & $\%$ & Number & $\%$ & \\
\hline \multirow{2}{*}{$\begin{array}{l}\text { Is there an age for organ donation? } \\
\text { (Can be donated at any age) }\end{array}$} & Yes & 6 & 2.2 & 278 & 98.5 & \multirow[t]{2}{*}{$<0.001^{* *}$} \\
\hline & No & 276 & 97.8 & 4 & 1.5 & \\
\hline \multirow{2}{*}{$\begin{array}{l}\text { Is it enough for a person to say that he } \\
\text { or she verbally donates their organs? }\end{array}$} & Yes & 275 & 97.5 & 3 & 1.1 & \multirow[t]{2}{*}{$<0.001^{* *}$} \\
\hline & No & 7 & 2.5 & 279 & 98.9 & \\
\hline \multirow{2}{*}{$\begin{array}{l}\text { Do you have enough information } \\
\text { about organ donation? }\end{array}$} & Yes & 5 & 1.8 & 280 & 99.2 & \multirow[t]{2}{*}{$<0.001^{* *}$} \\
\hline & No & 277 & 98.2 & 2 & 0.8 & \\
\hline \multirow{3}{*}{$\begin{array}{l}\text { Is tissue compliance necessary for } \\
\text { organ donation? }\end{array}$} & Yes & 2 & 0.7 & 279 & 99.0 & \multirow[t]{3}{*}{$<0.001^{* * *}$} \\
\hline & No & 28 & 9.9 & 2 & 0.7 & \\
\hline & I dont know & 252 & 89.4 & 1 & 0.3 & \\
\hline \multirow{3}{*}{$\begin{array}{l}\text { Is blood compliance necessary for } \\
\text { organ donation? }\end{array}$} & Yes & 3 & 1.1 & 279 & 99.0 & \multirow[t]{3}{*}{$<0.001 * * *$} \\
\hline & No & 5 & 1.8 & 2 & 0.7 & \\
\hline & I dont know & 274 & 97.1 & 1 & 0.3 & \\
\hline \multirow{3}{*}{$\begin{array}{l}\text { Do you think it is legally appropriate } \\
\text { to sell organs for money in our } \\
\text { country? }\end{array}$} & Yes & 4 & 1.5 & 1 & 0.3 & \multirow[t]{3}{*}{$<0.001 * * *$} \\
\hline & No & 6 & 2.2 & 279 & 99.0 & \\
\hline & I dont know & 272 & 96.3 & 2 & 0.7 & \\
\hline \multirow{5}{*}{$\begin{array}{l}\text { * Under which circumstances can an } \\
\text { organ transplant be carried out from a } \\
\text { person who has not previously } \\
\text { requested organ donation? }\end{array}$} & $\begin{array}{l}\text { Two close } \\
\text { relatives } \\
\text { comfirmation }\end{array}$ & 2 & 0.7 & 282 & $\begin{array}{l}100 . \\
0\end{array}$ & \multirow[t]{5}{*}{$<0.001^{* * *}$} \\
\hline & $\begin{array}{l}\text { Brain death } \\
\text { occurs }\end{array}$ & 61 & 21.6 & 282 & $\begin{array}{l}100 . \\
0\end{array}$ & \\
\hline & $\begin{array}{l}\text { Stay in intensive } \\
\text { care }\end{array}$ & 107 & 37.9 & 282 & $\begin{array}{l}100 . \\
0\end{array}$ & \\
\hline & $\begin{array}{l}\text { Be connected to } \\
\text { artificial } \\
\text { respirator }\end{array}$ & 192 & 68.0 & 282 & $\begin{array}{l}100 . \\
0\end{array}$ & \\
\hline & $\begin{array}{l}\text { Doctor's } \\
\text { approval }\end{array}$ & 282 & $\begin{array}{l}100 . \\
0\end{array}$ & 282 & $\begin{array}{l}100 . \\
0\end{array}$ & \\
\hline \multirow[t]{9}{*}{ * Which organs can be donated? } & Heart & 9 & 3.1 & 282 & $\begin{array}{l}100 . \\
0\end{array}$ & \multirow[t]{9}{*}{$<0.001 * * *$} \\
\hline & Lungs & 3 & 1.1 & 282 & $\begin{array}{l}100 . \\
0\end{array}$ & \\
\hline & Liver & 232 & 82.2 & 282 & $\begin{array}{l}100 . \\
0\end{array}$ & \\
\hline & Cornea & 133 & 441.1 & 282 & $\begin{array}{l}100 . \\
0\end{array}$ & \\
\hline & Heart valve & 42 & 14.8 & 282 & $\begin{array}{l}100 . \\
0\end{array}$ & \\
\hline & Kidney & 280 & 99.2 & 282 & $\begin{array}{l}100 . \\
0\end{array}$ & \\
\hline & Pancreas & 2 & 0.7 & 282 & $\begin{array}{l}100 . \\
0\end{array}$ & \\
\hline & Small intestine & 1 & 0.3 & 282 & $\begin{array}{l}100 . \\
0\end{array}$ & \\
\hline & All & 7 & 2.4 & 282 & $\begin{array}{l}100 . \\
0\end{array}$ & \\
\hline
\end{tabular}

* More than one option is marked.

**McNemar test

***McNemar-Bowker test 
Table 3. Distribution of the attitudes of nursing students about organ donation

\begin{tabular}{|c|c|c|c|c|c|c|}
\hline \multirow{2}{*}{\multicolumn{2}{|c|}{ Attitude }} & \multicolumn{2}{|c|}{ Before education } & \multicolumn{2}{|c|}{ After education } & \multirow[t]{2}{*}{$\mathrm{p}$} \\
\hline & & \multirow{2}{*}{$\begin{array}{l}\text { Number } \\
185\end{array}$} & \multirow{2}{*}{$\begin{array}{l}\% \\
65.7\end{array}$} & \multirow{2}{*}{\begin{tabular}{|l|} 
Number \\
250
\end{tabular}} & \multirow{2}{*}{$\begin{array}{l}\% \\
86.8\end{array}$} & \\
\hline Do you want to receive organs from & Yes & & & & & $<0.001^{*}$ \\
\hline people you don't know about someone & No & 68 & 24.1 & 21 & 9.4 & \\
\hline $\begin{array}{l}\text { transplantation in your relatives or } \\
\text { relatives? }\end{array}$ & $\begin{array}{l}\text { Relationship } \\
\text { affiliated }\end{array}$ & 29 & 10.2 & 11 & 3.8 & \\
\hline \multirow{3}{*}{$\begin{array}{l}\text { Would you like to donate your own } \\
\text { organs to someone who is waiting for } \\
\text { organ transplantation in your relatives } \\
\text { or near you? }\end{array}$} & Yes & 10 & 3,5 & 174 & 61.7 & \multirow[t]{3}{*}{$<0.001^{*}$} \\
\hline & No & 245 & 86.9 & 61 & 21.6 & \\
\hline & $\begin{array}{l}\text { Relationship } \\
\text { affiliated }\end{array}$ & 27 & 9.6 & 47 & 16.6 & \\
\hline \multirow{3}{*}{$\begin{array}{l}\text { Would you accept that your relatives } \\
\text { or relatives of others who are waiting } \\
\text { for organ transplant near you, donate } \\
\text { their organs to other relatives? }\end{array}$} & Yes & 48 & 17.2 & 122 & 43.2 & \multirow[t]{3}{*}{$<0.001^{*}$} \\
\hline & No & 97 & 34.3 & 19 & 6.8 & \\
\hline & $\begin{array}{l}\text { Relationship } \\
\text { affiliated }\end{array}$ & 137 & 48.5 & 141 & 50.0 & \\
\hline \multirow{3}{*}{$\begin{array}{l}\text { Would you like to donate organs to } \\
\text { someone else who is waiting for the } \\
\text { organ to be transplanted, even if you } \\
\text { have brain death in one of your } \\
\text { relatives or your relatives? }\end{array}$} & Yes & 11 & 3.8 & 20 & 7.1 & \multirow[t]{3}{*}{$<0.001^{*}$} \\
\hline & No & 162 & 57.4 & 65 & 23.1 & \\
\hline & $\begin{array}{l}\text { Relationship } \\
\text { affiliated }\end{array}$ & 109 & 38.8 & 187 & 69.8 & \\
\hline
\end{tabular}

* McNemar-Bowker test

\section{Discussion}

Studies on organ transplantation and donation have shown that the participants' views are significantly influenced by factors such as education, socio-economic level, culture and religion, the concern that the organs will be given to someone they do not want as a recipient, and the fact that organ donation reminds of death (Sıpkın et al, 2010; Özer-Gök, 2018; Göz, 2007; Savaşer et al, 2012; Vicdan et al, 2011). In a study in Brazil, it was found that although people believe in the necessity for organ donation, they do not become donors particularly because of the fear of organ trafficking and trade (Mazzia et al, 2015). Similarly to the literature; the fear of being killed, lack of education, belief and family structure were found in this study to have an effect on the decision to become a donor. Studies have found that the ideal age range for organ donation is between 18-55 years of age, although studies in Turkey have found that average age of living donors was over 40 years (Yakupoglu et al, 2009, Yuksel et al, 2014;Ozden et al, 2010), whereas the average age of cadaver donors was over 34 years (Yuksel et al, 2014). When all these data are taken into consideration, it is thought that managing this process and increasing the donation rate can only be achieved by performing training on the importance of organ donation and the ethics of the donation process.

Similarly to other studies in the world and in Turkey, this study also revealed that nursing students were not aware of the concept of brain death, that they did not know the criteria for organ transplantation, and that they did not have sufficient information about organ donation; however, they still exhibited a positive attitude towards organ donation (Vicdan et al, 2011; Zampieron et al, 2010; López-Montesinos et al, 2010; Kocaay et al, 2015; Sarı̈öl Ordin et al, 2018; Cerrato et al, 2017). Although there are training activities held after graduation in Turkey to address these shortcomings, it is obvious that newlygraduated nurses cannot play an effective role in the cases of brain death until they take such a training. In a study conducted with Japanese students, it was reported that $30.5 \%$ of the students were organ donors (Bagheri et al,2003). In the present study, it was determined that only $1.1 \%$ of the students were organ donors before the education. This ratio is very low for the nursing profession, which is one of the primary occupations in a position to convince families in becoming donors.

An evaluation of the answers given before and after the education to the questions assessing the attitudes towards organ donation reveals that the percentage of those who stated that they could donate the organs of one of their close relatives increased significantly compared to the pre-education level. These improvements in the answers provided to the questions regarding attitude can be explained by the fact 
that the students attained an adequate level of knowledge about organ donation. Knowing the diagnosis of brain death and accepting this diagnosis will prevent the unnecessary occupation of beds in intensive care units, thus providing greater access to services for patients in need. At the same time, organ donation by the relatives of patients with brain death will result in a decrease in healthcare costs at both the personal and the social level through the effective treatment of people in need of an organ. Nurses should have sufficient knowledge about the diagnosis of brain death and organ donation, such that families can more easily accept the diagnosis of brain death and become donors (Aghayan et al, 2009). There is data showing that training on organ donation increases volunteerism in different groups (Ramandeep et al, 2014; Garcia et al, 2008; Reubsaeta et al, 2005).

In a study investigating the reasons for the low number of donors despite the general public support for organ donation, it was stated that while nurses providing end-of-life care had a positive attitude about organ donation, they were uncertain about whether guiding patients and their families to donate organs was within the scope of the nursing practice, which was one of the reasons for the low ratio of donations (Crymble et al, 2017). In another study, it was stated that healthcare workers also need information about organ donation, that an increase in the level of education increased the level of knowledge and positive attitudes regarding organ transplantation, and that training activities would help improve the positive attitudes towards organ donation (Guerra-Sáenz et al, 2016).

\section{Conclusion}

The present study is important in that it shows that giving this training at the undergraduate level will impact the awareness and acceptance rate to an even greater extent. Furthermore, the addition of organ donation to the curriculum of nursing students at the undergraduate level makes our study superior to other studies in terms of increasing awareness in the early period and long term. Organ transplantation and organ donation are becoming a global issue due to the increase in chronic diseases. With appropriate curriculum changes in undergraduate education, it will be possible to train healthcare professionals with sufficient knowledge and persuasiveness on this subject.

\section{References}

[1] Reville, P., Zhao, C., Perez, T., Nowacki, A.S., Phillips, D., Bowen, G., et al. (2013). A student leadership model for promoting educational programs in organ donation and transplantation. Transplant Proc,45(4),1287-94.

[2] T.C. Sağlık Bakanlığı Organ ve Doku Nakli Hizmetleri Yönetmeliği. [Erişim Tarihi:12.02.2019]; Erişim: http://www.saglik.gov.tr/TR/belge/1-560/organ-ve-doku-naklihizmetleri-yonetmeligi.htm.

[3] Sipkın, S., Sen, B., Akan, S., Malak, T. (2010). Onsekiz Mart Üniversitesi Tıp Fakültesi, İlahiyat Fakültesi ve Güzel Sanatlar Fakültesi ögretim elemanlarının organ bağışına bakış açılarının incelenmesi. ADÜ Tip Fakültesi Dergisi,11(1), 19-25.

[4] Demir Doğan, M., Uzun, İ., Kaya, N., Ekinci, H., Altınkaynak, M. (2016). Üniversite öğrencilerinin organ bağışına bakış açısı ve bilgi düzeyleri. $H S P, 3(2), 99-105$.

[5] Webb, G., Phillips, N., Reddiford, S., Neuberger, J. (2015). Factors affecting the decision to grant consent for organ donation: a survey of adults in England. Transplantation,99,1396-1402.

[6] Barbara, J.D. (2006). End of life decision making. Organ Donation and Critial Care Nurses, 126(2),78-86.

[7] Alsaied, O., Bener, A., Al-Mosalamani, Y., Nour, B. (2012). Knowledge and attitudes of health careprofessionals toward organ donation andtransplantation. Saudi J Kidney Dis Transpl, 23(6),1304-1310.

[8] Yilmaz, T.U. (2011). Importance of education in organ donation. Exp Clin Transplantation, 9(6),370-5. 
[9] Akgün, H.S., Bilgin, N., Haberal, M., Kut, A., Tokalak, I. (2003). Organ donation: A crosssectional survey of the knowledge and personal viewsof Turkish health care professionals. Transplantation Proceedings, 35:1273-1275.

[10] Michetti, C.P., Nakagawa, T.A., Malinoski, D., Wright, C., Swanson, L. (2016). Organ donation education initiatives: A report of the Donor Management Task Force. J Crit Care, 35:24-8.

[11]Özer, Gök. F., Yavuz, A., Beydağı, K.D., Fidancıoglu, H., Akın, E., Sanlı, I., Tembela, H., Bozkurt, L., Urak, S. (2008). Pamukkale Üniversitesi Denizli Yüksek Okulu'nda ögrenim gören bir grup ögrencinin organ nakli ve bakısına yönelik görüşleri ve bilgi düzeylerine eğitimin etkisi. TSK Koruyucu Hekimlik Bülteni, 7(1):39- 46.

[12] Göz, F., Gürelli, S. (2007). Yoğun bakım hemşirelerinin organ bağısı ile ilgili düşünceleri. Fırat Sağllk Hizmetleri Dergisi, 2 (5):77-88.

[13] Güden, E.A. (2007). Din görevlilerinin organ nakli ve bagısına bakıs açıları. Yüksek Lisans Tezi, Kayseri: Halk Sağlı̆̆ AD.

[14] Savaşer, S., Mutlu, B., Çağlar, S., Doğan, S., Canbulat, N. (2012). "Senior nursing schools students' views on organ donation". Florence Nightingale Journal of Nursing, 20(1), 1-9.

[15] Vicdan, A.K., Peker, S., Uçer, B. (2011). "Determination of the attitudes of aksehir health high school students concerning organ donation". TAF Prev Med Bull, 10(2),175-180.

[16] Mazzia, A.F., Hoppen, C.M., Isquierdo, L.D., Bourlegat, M.L., Picasso, M.C., Kissmann, N., Gallo, R.B., Júnior, S.P., Guimarães, V.B., Garcia, C.D., Castro, E.D., Garcia, V.D. (2015). What is organ donation and transplantation? Educating through the doubt. Transplant Proc, 47(4):879-81.

[17] Yakupoglu, Y.K., Ozden, E., Kocak, B., Dilek, M., Akpolat, T., Arik, N., Cengiz, K., Adibelli, Z., Ozkaya, O., Durupinar, B., Eren, Tulek, N., Danac,i M,, Ceylan, L, \& Sarikaya, S. (2009). Three years of kidney transplantation experience at a university hospital. Turkish Nephrology, Dialysis and Transplantation Journal, 18,76-81.

[18] Yuksel, H., Cinar, Y., Sahin, M., Ozer, Z., Evreoz, Y., Sener, T., Cingu, A.K. (2014). The effects of epidemiological characteristics of cornea donors and donor corneal evaluation parameters on quality of donor cornea. Dicle Medical Journal, 41,341-346.

[19] Ozden, E., Yakupoglu, Y.K., Bostanci, Y., Atac, F., Karatas, A., Sarikaya, S. (2010). Results of retroperitoneoscopic donor nephrectomy at our center. Turkish Nephrology, Dialysis and Transplantation Journal, 19,180-185.

[20]Zampieron, A., Corso, M., Frigo, A.C. (2010). Undergraduate nursing students' attitudes towards organ donation: a survey in an Italian university. Int Nurs Rev, 57(3),370-6.

[21] López-Montesinos, M.J., Manzanera Saura, J.T., Mikla, M., Ríos, A., López-Navas, A, Martínez-Alarcón L, et al. Organ donation and transplantation training for future professional nurses as a health and social awareness policy. Transplant Proc, 42(1),239-42.

[22] Kocaay, A.F., Celik, S.U., Eker, T, Oksuz, N.E., Akyol, C., Tuzunerü A. (2015). "Brain death and organ donation: Knowledge, awareness, and attitudes of medical, law, divinity, nursing, and communication students". Transplantation Proceedings, 47(5),1244-1248.

[23] Sarıöl-Ordin, Y., Bilik, Ö., Akpınar-Söylemez, B. , Kankaya, E., Çelik, B, Duğrul E. (2018). Organ bağışına yönelik öğrenci tutumları: hemşirelik. Gümüşhane Üniversitesi Sağllk Bilimleri Dergisi,7 (2), 28-36. 
[24] Cerrato A, Ea E, Flom P. (2017). Evaluating the need for organ donation and transplant-related education in nursing curricula. Nurs Educ Perspec, 38(4):209-11.

[25] Bagheri, A., Tanaka, T., Takahashi, H., Shoji, S. (2003). Brain death and organ transplantation:knowledge, attitudes, and practice among Japanese students. Eubios J Asian Int Bioeth, 13, 3-5.

[26] Aghayan, H.R., Arjmand, B., Emami-Razavi, S.H., Jafarian, A., Shabanzadeh, A.R., Jalali, F. (2009). Organ donation workshop - a survey on nurses' knowledge and attitudes toward organ and tissue donation in Iran. Int J Artif Organs, 32(10), 739.

[27] Ramandeep, K., Nilavansa, B., Amritpal, K. (2015). Aquasi experimental study to assess the effectiveness of structured teaching programmeon knowledge and attitude regarding organdonation among young adults in selected col-leges of Jalandhar, Punjab 2014. Asian Journal of Nursing Education and Research, 5(1),140-145.

[28] Garcia, C.D., Barboza, A.P., Goldani, J.C., Neumann, J., Chem, R., Camargo, J., et al. Educational program of organ donation andtransplantation at medical school. Transplantation Proceedings, 40,1068-1069.

[29] Reubsaeta, A., Brug, J., Nijkamp, M.D., Candel, M.J., van Hooff JP, van den Borne HW. Theimpact of an organ donation registration information program for high school studentsin the Netherlands. Social Science \& Medicine, 60,1479-1486.

[30] Crymble, K., Fabian, J., Etheredge, H., Gaylard, P. (2017). Perceptions of nurses' roles in endof-life care and organ donation - imposition or obligation? S Afr Med J, 107(7),573-5.

[31] Guerra-Sáenz, E.K., Narváez-Navarro, Á., Hernández-López, A.C., Saucedo, J.B., Ruiz-Cantú, G., Cordero-Pérez, P., et al. (2016). Organ and tissue donation and transplantation: three health care centers' attitude. Gac Med Mex, 152(5),668-98. 